1 ANALYTICAL SCIENCE

4 \& TECHNOLOGY

Vol. 26, No. 6, 401-406, 2013

http://dx.doi.org/10.5806/AST.2013.26.6.401

\title{
Analysis of respiration gas of a fertile chicken egg during incubation by gas mass spectrometer
}

\author{
Hyunjoo Kim, Deullae Min'1, Dalho Kim ${ }^{1}$ and Jin Seog Kim ${ }^{1, \star}$ \\ School of Liberal Arts and Sciences, Korea National University of Transportation, 50 Daehak-Ro \\ Chungju, Chungbuk, 380-702, Korea
}

${ }^{1}$ Korea Research Institute of Standards and Science, 209 Gajeong-Ro, Yuseong-Gu, Daejeon 305-340, Korea

(Received November 26, 2013; Revised December 10, 2013; Accepted December 10, 2013)

\section{기체질량분석기를 이용한 유정란 부화과정의 호흡량 분석}

\author{
김현주 · 민들레 ${ }^{1}$ 김달호 ${ }^{1} \cdot$ 김진석 ${ }^{1} \star \star$ \\ 한국교통대학교 교양학부, 1 한국표준과학연구원 \\ (2013. 11. 26. 접수, 2013. 12. 10. 수정, 2013. 12. 10. 승인)
}

\begin{abstract}
Oxygen $\left(\mathrm{O}_{2}\right)$ consumption and carbon dioxide $\left(\mathrm{CO}_{2}\right)$ excretion of a fertile chicken egg during incubation were measured by a gas mass spectrometer. A closed sample chamber was developed to collect gas samples during the 20 days of artificial incubation of both a fertile and an infertile egg. After leaving an egg in the sample chamber for an hour, using a gas-tight syringe, samples of $2 \mathrm{~mL}$ of gas were collected from the closed sample chamber and analyzed using a gas mass spectrometer in $2 \sim 4$ day intervals. The $\mathrm{O}_{2}$ consumption and $\mathrm{CO}_{2}$ excretion of chicken embryos increased rapidly after 10 days from the starting point of incubation. After 20 days, $23 \mathrm{~mL}$ of $\mathrm{O}_{2}$ was consumed and $16 \mathrm{~mL}$ of $\mathrm{CO}_{2}$ was excreted per hour. Throughout the whole period of incubation, concentration of $\mathrm{O}_{2}$ decreased $4.3 \mathrm{~mol} \%$ and $\mathrm{CO}_{2}$ increased only $3.1 \mathrm{~mole} \%$, i.e., the mole of consumed $\mathrm{O}_{2}$ and the mole of excreted $\mathrm{CO}_{2}$ were not the same. On the other hand, during the same period, concentration of $\mathrm{N}_{2}$ increased about $1.3 \mathrm{~mol} \%$ and the increased mole fraction of $\mathrm{N}_{2}$ was comparable with the difference $(1.2 \mathrm{~mol} \%)$ between the mole fraction of consumed $\mathrm{O}_{2}$ and excreted $\mathrm{CO}_{2}$. Therefore, we can attribute the increase of $\mathrm{N}_{2}$ mole $\%$ to the difference of mole fraction between consumed $\mathrm{O}_{2}$ and excreted $\mathrm{CO}_{2}$. In this study, through the analysis of gas, we could explain the respiration of a fertile chicken egg during incubation.
\end{abstract}

요 약: 유정란의 부화과정 동안 소모되는 산소와 배출되는 이산화탄소의 양을 기체질량분석기를 사용 하여 측정하였다. 20 일에 걸친 유정란과 무정란의 인공부화 과정 동안 기체 시료를 채취하기 위해 밀폐 된 구조의 시료 챔버를 제작하였다. 2 4 일 간격으로 시료 챔버 안에 유정란을 1 시간 동안 방치한 후, 실린지를 이용해 밀폐된 시료 챔버로부터 $2 \mathrm{~mL}$ 의 기체 시료를 채취한 후 기체질량분석기를 사용하여 분 석하였다. 인공부화를 시작한 후 약 10 일 후부터 닭 배아의 산소 소모량과 이산화탄소 배출량이 급격히 증가하였다. 20 일 후에는 시간당 $23 \mathrm{~mL}$ 의 산소를 소모하고 $16 \mathrm{~mL}$ 의 이산화탄소를 배출하였다. 전체

Corresponding author

Phone : +82-(0)42-868-5003 Fax : +82-(0)42-868-5033

E-mail : jkim@kriss.re.kr 
부화 기간 동안 산소의 농도는 $4.3 \mathrm{~mol} \%$ 감소하였고 이산화탄소의 농도는 $3.1 \mathrm{~mole} \%$ 증가하여 소모된 산소의 몰수와 배출된 이산화탄소의 몰수가 같지 않았다. 한편, 동일한 기간 동안 질소의 농도는 약 1.3 $\mathrm{mol} \%$ 증가하였으며 그 증가된 농도는 소모된 산소와 배출된 이산화탄소의 농도변화량의 차이와 비슷한 값을 보였다. 따라서 질소의 몰분율 증가는 소모된 산소와 배출된 이산화탄소 간의 몰분율 차이에 의한 것임을 알 수 있었다. 본 연구에서는 기체의 조성 변화량을 정확히 측정하여 유정란의 부화과정 중 호흡 현상을 설명할 수 있었다.

Key words: artificial incubation, gas mass spectrometer, standard gas, oxygen, carbon dioxide, respiration

\section{1. 서 론}

호흡현상은 생명체의 생체 신호 중 하나로 생리학 적 변화와 성장과정을 설명할 수 있는 지표가 될 수 있기 때문에 호흡량의 측정방법에 대하여 여러 분야 에서 연구가 진행되어 오고 있다. 특히 인간의 호흡량 은 건강상태나 질병의 유무를 판단하는 근거가 되므 로 산소의 소모량이나 이산화탄소의 배출량을 측정하 는 방법이 널리 알려져 있다. 호흡량 측정을 위해 혈 액가스분석기를 이용하여 산소의 분압이나 이산화탄 소의 분압을 측정하거나 가스분석기를 사용하여 호흡 가스 내의 산소와 이산화탄소의 농도를 측정하기도 한다. ${ }^{1-2}$ 최근에는 센서를 이용하여 혈액내의 산소 분 압을 측정할 수 있는 정밀기구가 개발되는 등 측정기 구가 소형화되고 있다. ${ }^{3}$

과채류의 경우, 저장온도 및 이산화탄소의 농도가 후숙 및 부패에 미치는 영향이 크기 때문에 과채류의 호흡량 측정을 위해 밀폐된 시스템에서 이산화탄소의 배출량을 적외선 가스분석기와 가스크로마토그래프를 사용하여 측정한다. ${ }^{4-6}$

유정란의 경우, 배아가 성장함에 따라 산소를 운반 하는 헤모글로빈을 포함하는 적혈구가 증가하고, 이에 따라 산소의 소모량이 증가하고, 호흡량이 증가한다. 부화기간에 따른 배아의 혈액을 분석함으로써 적혈구 의 생성량과 호흡량과의 상관관계를 밝힌 연구가 수 행되기도 했다. ${ }^{7}$ 이처럼 호흡량을 측정하는 원리 및 방법은 매우 다양하다.

본 연구에서는 유정란의 부화과정 중 호흡량의 변화 를 알아보기 위해 비교적 간편하면서도 정확한 분석방 법으로, 유정란의 호흡가스를 시료로 택하여 시료중의 산소와 이산화탄소의 농도의 변화를 살펴보고자 한다. 부화과정은 공기가 순환되는 시스템에서 이루어지기 때문에 호흡으로 인한 공기조성의 변화량을 정확히 측 정하기 위해서는 밀폐된 측정시스템의 개발이 필요하
다. 따라서 본 연구에서는 기체 시료 포집을 위한 시료 챔버를 제작하였고, 밀폐된 챔버 안에 일정시간 유정란 을 방치한 후 챔버 안의 기체를 취하여 소모된 산소와 배출된 이산화탄소의 양을 측정하였다. 기체 시료의 성 분분석을 위해서 기체질량분석기를 이용하여 몰분율을 측정하였으며, 호흡량 비교를 위해 무정란을 대상으로 유정란과 같은 조건에서 실험을 수행하였다.

\section{2. 실 험}

\section{1. 실험기구}

유정란을 부화시키기 위해 시중에서 판매하는 소형 인공부화기를 사용하였다. 부화과정에 따른 기체 시 료 채취를 위해 밀폐된 구조의 원통형 시료 챔버 (sample chamber)를 테플론 소재로 제작하였다. 시 료 챔버 상단에는 기체 시료를 취할 수 있도록 격막 (septum)이 달린 채취구(sampling port)를 설치하였 다. 챔버의 부피는 $592 \mathrm{~mL}$ 이었으며 기체 시료는 실 린지를 사용하여 채취하여 기체질량분석기에 주입하 였다(Fig. 1).

\section{2. 시료 채취}

계란의 부화 기간은 21 일이므로 무정란과 유정란

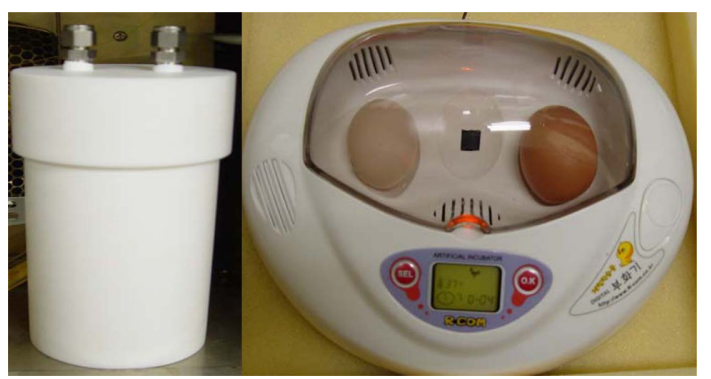

Fig. 1. Photographs of the sample chamber and a commercial incubator. 
각각 1 개를 준비하여 부화기에 넣은 후 최적 부화온 도로 발육기인 1 일부터 19 일 동안은 부화기의 온도 를 37.5 37.7 ${ }^{\circ} \mathrm{C}$ 로 유지하고 발생기인 20 일부터 21 일 동안은 $36.1 \sim 37.2{ }^{\circ} \mathrm{C}$ 로 유지하였다. 일정 기간이 경과한 후 무정란과 유정란을 각각 꺼내어 시료 챔버 에 넣어 밀폐한 후 부화기의 온도와 동일하게 온도를 맞춰 예열한 오븐 속에서 1 시간 동안 방치하여 계란 의 호흡과정에서 흡수 또는 발생되는 기체 성분들이 시료 챔버 내의 공기와 안정적인 평형을 유지하도록 하였다. 1 시간 후 gas-tight syringe를 사용하여 시료 챔버 내의 기체 $2 \mathrm{~mL}$ 를 취해 기체질량분석기를 사용 하여 질소, 산소, 이산화탄소의 농도를 측정하였다. 기 체 시료를 채취한 후 시료 챔버 속에 있는 계란을 시 간 지체 없이 부화기에 다시 넣고 다음 측정기간이 도래할 때까지 부화과정이 지속되도록 하였으며 20 일 동안 2 4 일 간격으로 위의 과정을 반복하여 기체 시료를 채취하고 즉시 분석하였다. 또한 유정란과 무 정란이 밀폐된 시료 챔버에 들어있는 시간을 1 시간 정도로 최소화하고 기체 시료를 소량 채취함으로써 시료 채취에 따른 압력 변화와 호흡에 따른 공기 조 성 변화가 유정란과 무정란의 생체에 미치는 영향이 없도록 주의하였으며 유정란의 경우 20 일 경과 후 건강한 병아리로 부화되는 것을 확인하였다. 유정란과 무정란을 비교하기 위해 모든 시료 준비과정을 동일 하게 유지하였다.

\section{3. 표준가스 및 액화혼합가스}

기체의 종류에 따라 질량분석기의 감도(sensitivity) 가 다르므로 질소, 산소, 이산화탄소의 측정을 위해 인증표준가스를 사용하여 질량분석기를 교정한 후 채 취한 기체 시료를 측정하였다. 본 실험에서 질량분석 기의 교정을 위해 사용한 표준가스는 건조공기 조성 을 갖는 표준가스와 $100 \mathrm{~mol} / \mathrm{mol}$ 의 이산화탄소 표준 가스이며 질소, 산소, 이산화탄소, 아르곤 성분에 대하 여 교정하였다. 본 연구에 사용한 인증표준가스는 모 두 중량법으로 한국표준과학연구원 대기환경표준센터 에서 제조하였고, 국제비교를 통해 정확도가 보증된 혼합가스이다. ${ }^{8-9}$

\section{4. 분석기기}

시료 챔버에서 채취한 기체 시료의 산소, 이산화탄 소 및 질소의 몰분율 측정을 위해 기체질량분석기 (Mass spectrometer for gas analysis, MAT271, Finigan, Germany)를 사용하였다. 이 질량분석기는 시료주입부와
단일 초점 자석식 질량분석계(single focusing magnetic sector) 그리고 세 개의 faraday collector와 한 개의 electron multiplier로 구성된 검출기를 갖추고 있다. 시 료의 주입은 분자흐름(molecular flow)을 이용하므로 질량분석기의 감응신호는 가스의 종류나 압력에 영향 을 받지 않고 가스의 농도에 비례한다. 본 실험에 사 용한 질량분석기는 직선성 범위 $\left(1 \times 10^{6}\right)$ 가 넓으므로 고 순도 가스나 농도를 정확히 아는 표준가스(일차표준 가스)를 사용하여 한 점 보정으로 단일 가스 종에 대 해 넓은 범위의 농도를 정확히 측정할 수 있다. ${ }^{10}$ 한 점 교정의 필요조건은 검정곡선이 원점을 지나는 직 선이어야 하는데 다양한 농도의 표준가스를 이용하여 직선성을 조사한 결과 제시한 불확도 수준에서 한 점 교정 조건을 만족함을 알 수 있었다. 중량법으로 제조 한 표준가스(상대확장불확도: $\pm 0.1 \%, k=2$ )를 질량분 석기에 주입하고 이때의 압력, 농도 및 감응신호(출력 전압)로 각 가스 성분의 감도(sensitivity)를 구하여 질 량분석기를 교정하였다. 본 실험에서는 전자 가속전압 $8 \mathrm{kV}$, 이온화 방출전류(emission current) $60 \mu \mathrm{A}$ 조건 에서 분해능 250 으로 패러데이(Faraday) 검출기를 사 용하여 각 가스 성분의 농도를 동시에 측정하였다.

\section{3. 결과 및 고찰}

계란은 $36.1 \sim 37.7{ }^{\circ} \mathrm{C}$ 에서 21 일의 기간을 거쳐 병 아리로 부화한다. 부화과정의 기체 성분 변화를 기체 질량분석기를 사용하여 기간별로 분석하였으며 그 결 과를 Table 1 (유정란)과 Table 2 (무정란)에 나타냈다. 또한 유정란의 부화기간별 시간당 산소 소모량과 이 산화탄소 배출량을 측정하여 Table 3에 나타냈다.

공기는 대략 $78 \%$ 의 질소, $21 \%$ 의 산소, $0.93 \%$ 의 아 르곤, 미량의 이산화탄소, 수증기 등으로 이루어져 있 다. 본 연구에서는 계란 부화과정의 호흡에 따른 기체 의 조성 변화를 측정하기 위해 부피 $592 \mathrm{~mL}$ 의 시료

Table 1. Mole fraction(\%) of gas components in a sample chamber for a fertile egg during incubation

\begin{tabular}{cccc}
\hline \hline Day & Nitrogen & Oxygen & Carbon dioxide \\
\hline 4 & 78.1 & 20.8 & 0.1 \\
7 & 78.0 & 20.8 & 0.2 \\
11 & 78.3 & 20.2 & 0.5 \\
15 & 78.9 & 18.3 & 1.9 \\
17 & 79.3 & 17.0 & 2.8 \\
20 & 79.4 & 16.5 & 3.2 \\
\hline
\end{tabular}


Table 2. Mole fraction(\%) of gas components in a sample chamber for an infertile egg during incubation

\begin{tabular}{cccc}
\hline \hline Day & Nitrogen & Oxygen & Carbon dioxide \\
\hline 1 & 78.1 & 20.9 & 0.1 \\
7 & 78.0 & 20.9 & 0.1 \\
13 & 78.1 & 20.9 & 0.1 \\
17 & 78.2 & 20.8 & 0.1 \\
20 & 78.1 & 20.9 & 0.1 \\
\hline
\end{tabular}

Table 3. Amounts of consumed oxygen and excreted carbon dioxide per hour during incubation $(\mathrm{mL} / \mathrm{h})$

\begin{tabular}{ccc}
\hline Day & Oxygen & Carbon dioxide \\
\hline \hline 4 & 0.4 & 0.4 \\
7 & 0.2 & 0.8 \\
11 & 3.5 & 2.6 \\
15 & 13.3 & 9.5 \\
17 & 20.0 & 14.1 \\
20 & 22.8 & 16.3 \\
\hline
\end{tabular}

챔버를 제작하고 그 속에 부화과정의 계란을 넣은 후 밀폐된 상태에서 1 시간 동안 방치하여 기체 성분의 조성 변화를 측정하였으므로 계란을 넣은 직후 시료 챔버 내 기체의 조성은 공기의 조성과 같다. 결과에서 볼 수 있는 바와 같이 유정란의 경우 7 일이 경과될 때까지 시료 챔버 내 기체의 조성에 큰 변화가 없는 것을 알 수 있다. 이는 부화기간별 시간당 산소 소모 량과 이산화탄소 배출량을 측정한 결과(Table 3)에서 알 수 있듯이 닭 배아의 성장 초기 단계에서는 호흡 량이 매우 작기 때문이라고 사료된다. 유정란의 경우 배아의 성장에 따라 호흡이 점점 더 활발해져 10 일 경과 후부터 산소와 이산화탄소의 조성이 급격히 변 하였다. 20 일 경과 후에는 산소의 소모량이 초기 소 모량의 약 60 배에 달했으며(Table 3, Fig. 2) 산소의 조성은 처음 대비 약 $20 \%$ (4.3 mol\%) 감소하고(Table 1, Fig. 3) 이산화탄소의 조성은 $3.1 \mathrm{~mol} \%$ 증가하였다 (Table 1, Fig. 4). 이 결과로부터 산소가 소비된 만큼 동일 몰의 이산화탄소가 호흡을 통해 배출되지 않는 것을 알 수 있었다. 반면 무정란에 대해 유정란과 동 일한 조건에서 시료를 준비하고 측정한 결과 부화기 간 전 과정에서 기체의 조성 변화는 관찰되지 않았으 므로(Fig. 3, 4) 시료 챔버 내 기체의 조성 변화는 닭 배아의 성장에 따른 호흡과정에 기인한 기체의 조성 변화임을 알 수 있다.

한편 공기의 주성분인 질소의 변화량을 측정한 결 과 질소의 몰분율이 시간 경과에 따라 서서히 증가함

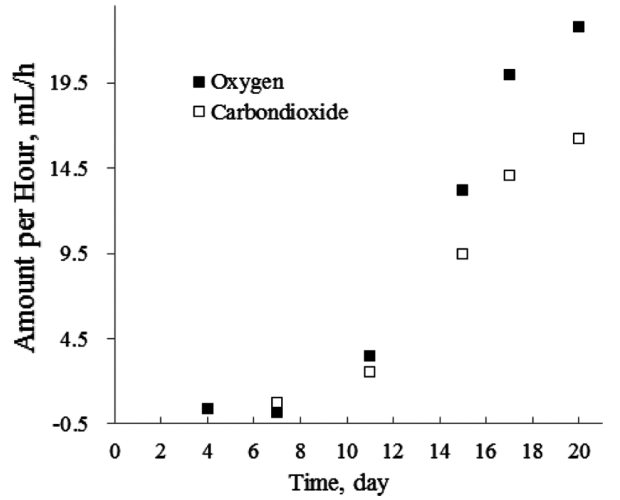

Fig. 2. Change of consumed oxygen amount and excreted carbon dioxide amount per hour during incubation.

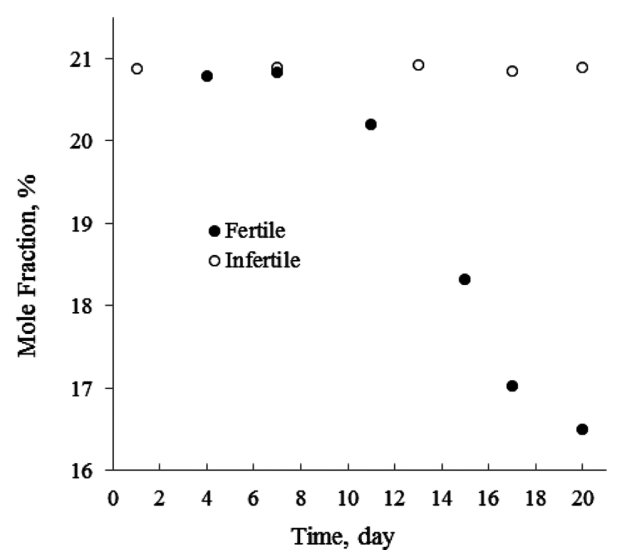

Fig. 3. Change of oxygen composition in a sample chamber during 20 days of incubation for a fertile and an infertile egg.

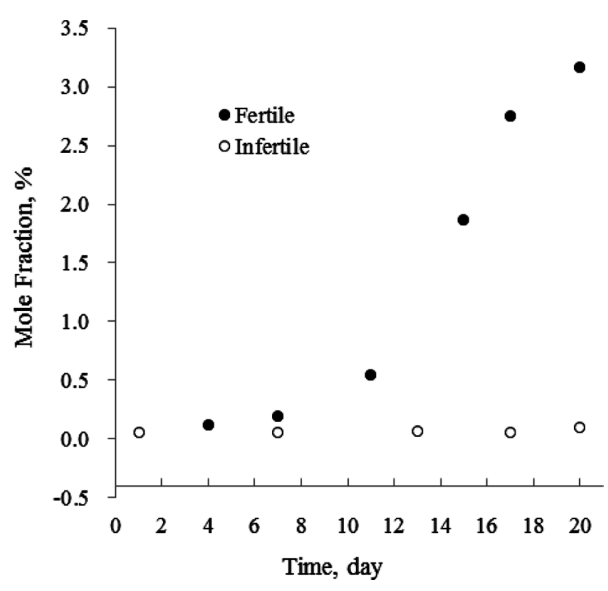

Fig. 4. Change of carbon dioxide composition in a sample chamber during 20 days of incubation for a fertile and an infertile egg. 


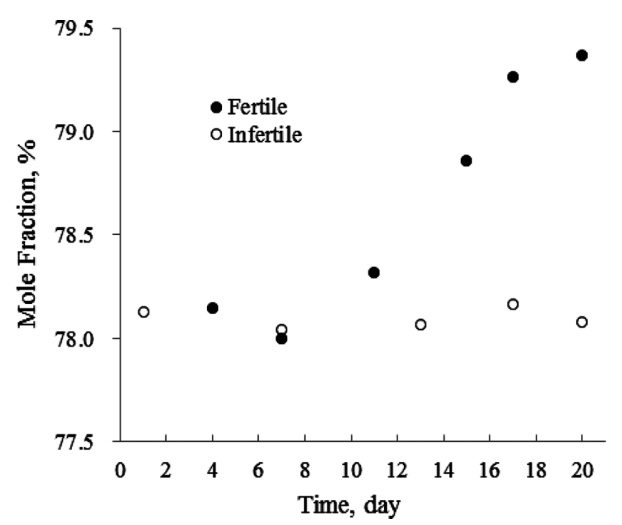

Fig. 5. Change of nitrogen composition in a sample chamber during 20 days of incubation for a fertile and an infertile egg.

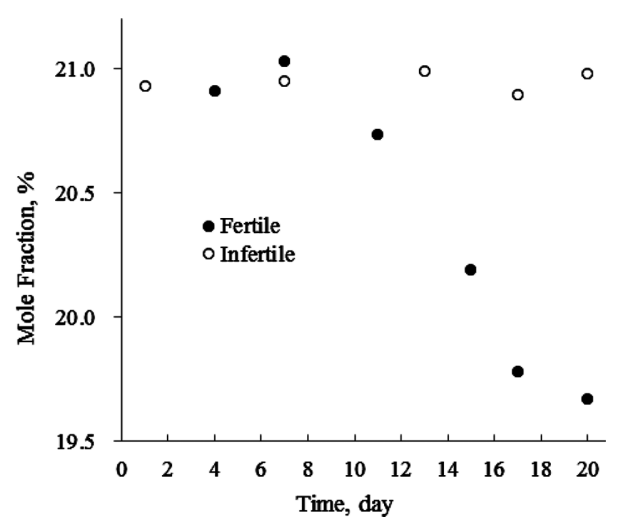

Fig. 6. Change of total oxygen and carbon dioxide composition in a sample chamber during 20 days of incubation for a fertile and an infertile egg.

을 알 수 있었다(Table 1, Fig. 5). 이 결과는 앞에 기 술한 바와 같이 산소가 소비된 만큼 동일 몰의 이산 화탄소가 호흡을 통해 배출되지 않기 때문에 그 조성 이 감소한 만큼 질소의 조성(mole fraction)이 상대적 으로 증가한 것으로 판단된다. Fig. 6에 부화기간별 산소와 이산화탄소의 몰수를 합한 조성변화를 나타냈 다. 만약 유정란의 산소가 소비된 만큼 동일 몰의 이 산화탄소가 호흡을 통해 배출되었다면 산소와 이산화 탄소의 몰수를 합한 값은 변화하지 않고 일정할 것이 다. 그러나 Fig. 6에 나타낸 것과 같이 산소와 이산화 탄소의 몰수를 합한 총몰분율은 서서히 감소하는 것 을 알 수 있으며 감소한 값은 $1.2 \mathrm{~mol} \%$ 이었다. 이 값 은 질소 몰분율의 변화량과 일치하므로 질소의 몰분 율이 증가하는 것은 이산화탄소 몰분율의 감소에 따 른 상대적인 증가로 볼 수 있다. 그러나 질소가 유정

Vol. 26, No. 6, 2013
란의 부화과정 중 대사에 의해 발생할 가능성도 배제 할 수 없으므로 생명체의 대사 현상에 의해 농도가 변하지 않고 일정한 아르곤을 질소와 함께 측정하였 다. ${ }^{11}$ 그 결과 아르곤의 몰분율도 질소의 몰분율이 증 가함에 따라 같은 비율로 증가하는 것을 확인하였다. 따라서 질소의 몰분율이 증가하는 것은 이산화탄소 몰분율의 감소에 따른 상대적인 증가로 결론지을 수 있었다.

\section{4. 결 론}

본 연구에서는 계란의 부화과정 중 유정란의 호흡 에 따른 기체의 조성 변화를 측정하기 위해 $592 \mathrm{~mL}$ 용량의 시료 챔버를 제작한 후 유정란과 무정란을 대 상으로 산소, 이산화탄소, 질소의 농도변화를 기체질 량분석기를 사용하여 측정하였다.

그 결과 유정란의 경우 10 일 경과 후부터 배아의 성장에 따른 호흡이 점점 더 활발해져 산소와 이산화 탄소의 조성이 급격히 변하였다. 20 일 경과 후에는 산소의 조성은 처음 대비 $20 \%(4.3 \mathrm{~mol} \%)$ 감소하고 이산화탄소의 조성은 $3.1 \mathrm{~mol} \%$ 증가하여 산소가 소 비된 만큼 동일 몰의 이산화탄소가 호흡을 통해 배출 되지 않는 것을 알 수 있었다.

공기의 주성분인 질소의 변화량을 측정한 결과 질 소의 몰분율이 시간 경과에 따라 서서히 증가하였고 그 결과는 산소가 소비된 만큼 동일 몰의 이산화탄소 가 호흡을 통해 배출되지 않기 때문에 그 조성이 감 소한 만큼 질소의 조성이 상대적으로 증가하는 것에 기인한 것으로 판단된다.

본 연구 결과, 계란의 부화과정 중 기체의 조성 변 화량을 정확히 측정하여 호흡과정을 설명할 수 있었 다. 조류의 부화과정 중 산소의 소모량과 이산화탄소 의 배출량은 종과 알의 크기에 따라 다르고 그 패턴 도 다르므로 간편하고 정확한 호흡량 분석방법이 요 구된다. 기체의 조성 변화량의 정확한 측정을 통해 호 흡량을 분석하는 본 분석방법은 앞으로 생명체 발생 과정의 호흡에 대한 연구와 최적의 부화조건 설정 연 구 등에 활용될 수 있을 것으로 기대된다.

\section{감사의 글}

이 논문은 2013년도 한국교통대학교 교내학술연구 비의 지원을 받아 수행한 연구임. 


\section{참고문헌}

1. D. U. Jeong. G. R. Jeon, J. W. Bae, G. J. Kim and Y. B. Sim, J. Sensor Sci. \& Tech., 12(1) 34-43 (2003).

2. C. U. Hong, H. S. Kang and G. B. Kim, J. Biomed. Eng. Res., 30, 147-152 (2009).

3. S. I. Ohira and K. Toda, Anal. Chim. Acta, 619, 143156 (2008).

4. Y. S. Park, C. Pelayo and T. Agar, J. Kor. Hort. Sci., 40(5), 563-566 (1999).

5. P. E. Haggar, D. S. Lee and K. L. Yam, J. Food Proc. Eng. 15(2) 143-157 (1992).

6. J. K. Park, J. K. Chun, S. K. Lee and K. H. Kim, Korean
J. Food Sci. Technol., 21(3) 387-390 (1989).

7. H. Tazawa, S. J. Andrewartha and W. W. Burggren, Comp. Biochem. Physiol. A. 159, 225-233 (2011).

8. S. Y. Park and J. S. Kim, Key Eng. Materials, 277, 523-527 (2005)

9. J. S. Kim, D. M. Moon, K, Kato, M. Maruyama, M. J. Kao, A. Botha and M. Dimashkiet, Metrologia, 40, Technical Suppliment No. 08009 (2003).

10. J. Y. Lee, H. S. Yoo, J. S. Park, K. J. Hwang and J. S. Kim, J. Chem. Edu. 82, 288-290 (2005).

11. S. Y. Park, J. S. Kim, J. B. Lee, M. B. Esler, R. S. Davis and R. I. Wielgosz, Metrologia, 41, 387-395 (2004). 